\title{
Sobre la huella de Constant: la crisis de representación y el retorno a la participación ciudadana
}

\author{
Maria Laura Eberhardt ${ }^{*}$
}

\begin{abstract}
Resumen
El presente artículo parte del debate filosófico en que se inserta el planteo de Constant respecto del modo diferencial en que se construyó la noción de libertad en las distintas épocas históricas, comenzando con la libertad positiva de los antiguos griegos hasta la conceptualización de libertad negativa de los modernos.

Tal posicionamiento invita a ahondar en el proceso concomitante de construcción de ciudadanía para las diversas perspectivas filosóficas y entornos democráticos a que corresponden, llegando a la conclusión de que, las dos formas en principio opuestas de percibir la participación política (directa, personal y activa para los antiguos atenienses e indirecta, representativa y pasiva para los individuos modernos), devienen complementarias en las repúblicas democráticas contemporáneas.

Dicha convivencia y complementariedad de ambas nociones de libertad política en el tramo actual de la historia aparece como el fundamento de una de las salidas sugeridas a la crisis del modelo de representación de masas vigente desde comienzos de los años '80: la creación de mecanismos semidirectos de participación popular, impulsada por los gobernantes para su aprovechamiento por los ciudadanos.

Palabras clave: Ciudadanía; Libertad; Participación política
\end{abstract}

\section{La libertad individual de los modernos en reemplazo de la libertad política antigua}

De las múltiples definiciones de ciudadanía disponibles en la bibliografía especializada, una en principio útil para iluminar la reflexión que convoca en esta oportunidad, sostiene que: "la ciudadanía es la condición política que nos permite participar en la definición de nuestro propio destino, es algo que o bien se acata o bien se ejerce" (Ruiz Silva, 2009:1)

\footnotetext{
* Doctora en Ciencia Política (UNSAM), con Magíster en Ciencia Política y Sociología (FLACSO) y Licenciada en Ciencia Política (UBA). Es también Posdoctoranda de la Facultad de Derecho (UBA), Profesora Titular de Sociología en la UNAJ, Profesora Adjunta de Ciencia Política en la UBA y Profesora Adjunta de Taller de Tesis en la UNLM. Directora de proyecto de investigación Ubacyt (UBA). Fue becaria doctoral, postdoctoral y de estadías posdoctorales en el exterior del CONICET, así como ha sido beneficiada con una Beca de la Fundación Carolina de España y el Ministerio de Educación argentino para realizar una segunda estancia de investigación posdoctoral en el exterior.. Email: laura rafaela@yahoo.com.ar.
} 
La originalidad y valor de dicha conceptualización radica en que involucra, en una única y misma frase, a las dos percepciones de libertad política, positiva (o activa y comunitaria) y negativa (o pasiva e individualista), antaño irreconciliables, estrictamente asociadas a dos épocas históricas altamente diferenciadas (antigua y moderna) y, durante cierto tiempo, asumidas como incompatibles.

Acercándonos a la noción política activa, positiva y comunitarista de libertad de los antiguos, en su libro Política Aristóteles advertía que "el hombre es por definición un animal político; por eso aun cuando no necesiten la mutua ayuda los hombres, no menos buscan la convivencia" (Aristóteles, 1998:118). Señalaba que "también los congrega la utilidad común, en cuanto que a cada uno le corresponde una parte del bienestar. Por tanto ese es principalmente su fin (...). Pero también se reúnen simplemente para vivir y constituyen la comunidad política" (Ídem). De ese modo, la condición primera y natural del hombre era la de convivencia en comunidad, donde el "individuo" moderno era impensable al igual que la sociedad concebida como una mera sumatoria de particularidades, ya que el todo resultaba ser cualitativamente superior a cada una de las partes (las que no existían plenamente fuera de aquél) y donde tomaba realidad el espacio compartido como base de la polis y único ámbito posible para la política.

Específicamente respecto "del político y del legislador" agregaba "que toda su actividad gira en torno a la ciudad; y el régimen político es una determinada organización de los habitantes de la ciudad", a la que concebía como "un conjunto de ciudadanos" (Ibídem:107). Decía que el ciudadano, que adquiría su condición de tal solamente en la ciudad, "no lo es por habitar en un lugar (pues también los metecos y los esclavos comparten el lugar de residencia) ni tampoco lo son necesariamente los que disfrutan de derechos jurídicos como para entablar un juicio o ser juzgados" (Ibidem:108). El ciudadano se definía fundamentalmente por "su participación en la justicia y en el gobierno" (Ídem). Lo era el que tenía participación como juez y asambleísta. Por otro lado, aclaraba que, al diferir los regímenes políticos entre sí, “también será necesariamente distinto el ciudadano de cada régimen político. Y así el que se ha citado en una democracia es sobre todo ciudadano, mientras que en los 
demás puede serlo, pero no necesariamente. Pues en algunos no hay pueblo ni tienen asamblea" (Ibidem:109).

Así que quién es el ciudadano, de lo anterior resulta claro: aquel a quien le está permitido compartir el poder deliberativo y judicial, este decimos que es el ciudadano de esa ciudad, y ciudad, en una palabra, el conjunto de tales personas capacitado para una vida autosuficiente (Ídem).

Como puede observarse, la actividad del tomar parte activa o participar personalmente en la deliberación asamblearia, era la que otorgaba al nativo la cualidad de ciudadanía, de la que se excluía por tanto a las mujeres, niños, esclavos y extranjeros.

De lo anterior surgía también que otra precondición para el ejercicio de la ciudadanía y la libertad en la Antigüedad era el verse previamente liberado de la atadura cotidiana de proveerse los materiales necesarios para la subsistencia como ser vivo, para lo cual existían los esclavos, obreros, comerciantes y mujeres. A juicio de Aristóteles "la ciudad mejor no hará ciudadano al obrero" y "la virtud (...) propia del ciudadano no se atribuirá a cualquiera, ni al libre solamente, sino a aquellos que estén exentos de los trabajos necesarios" (Ibídem:116). La actividad económica, lejos de haber constituido la meta, prioridad y razón máxima de vida de los antiguos griegos (a diferencia de lo que ocurriría más tarde entre los individuos modernos, al servicio de la cual colocarían incluso la regulación política de los asuntos comunes), quitaba al hombre el tiempo de ocio necesario para la deliberación pública superior, con lo que había que poder liberarse previamente de la carga económica esclavizadora para ejercer la libertad en la esfera política más elevada. Esa concepción se dejaría dilucidar más de una veintena de siglos después en la denuncia lanzada por Marx contra la sociedad capitalista moderna, según la cual, "la vida política se declara como un simple medio cuyo fin es la vida de la sociedad burguesa" (Marx, 1999:44):

Pero este hecho resulta todavía más misterioso cuando vemos que los emancipadores políticos rebajan incluso la ciudadanía, la comunidad política, al papel de simple medio para la conservación de estos llamados derechos humanos; que, por tanto, se declara al citoyen servidor del homme egoísta, se degrada la esfera en que el hombre se comporta como comunidad por debajo 
de la esfera en que se comporta como un ser parcial; que, por último, no se considera como verdadero y auténtico hombre al hombre en cuanto ciudadano, sino al hombre en cuanto burgués (Ibídem:43-44).

La cualidad de ser ciudadano otorgaba al hombre su dignidad plena y más elevada, la que se concretaba en la participación activa y personal en la asamblea soberana encargada de hacer la ley. Los extranjeros, mujeres, esclavos y niños quedaban por fuera de la "ciudad", por más que habitaran en el territorio de la polis, la que se definía por su dimensión política. Los derechos civiles modernos, ejercidos en el ámbito privado y propios del mercado, escindidos de la sociedad política o gobierno en sentido estricto, que, desde Locke en adelante fueron presentados como fundamentales y prioritarios al individuo y a los que los gobernantes debían servir y proteger, no tenían entidad alguna para los antiguos griegos.

Por el contrario, en aquella etapa histórica, el ser ciudadano se definía "por el ejercicio de cierto poder" (Aristóteles, 1998:110). Según Aristóteles, más que por herencia, esa cualidad se adquiría por el hecho concreto de participar en el régimen. $Y$ ese participar no era un eufemismo o un accionar que pudiese ser desplegado indirectamente, por otro en nombre de uno, o por un representante, sino una actividad que debía ejercerse en persona, en la institución política más importante que era la Asamblea, la única que hacía real la condición de ser libre como autonomía, donde el ciudadano formaba parte del cuerpo colectivo que producía la ley, la que luego regiría para todos y cada uno de los habitantes. El ciudadano se daba a sí mismo sus propias leyes, se autogobernaba, las normas que obedecía fuera de la Asamblea eran las mismas de cuya gesta había participado dentro de aquélla. Para todos las demás personas, ajenas a esta acción, las reglas aparecían como imposición externa, pura heteronomía, y, por ello, algo contrario o diferente de la libertad.

Finalmente, para el mundo antiguo, "la ciudad es una comunidad, y es comunidad de régimen político entre sus ciudadanos" (Ibídem:112), y no una sumatoria de individuos. Por ello era posible pensar en un bien común único, evidente y superior al de cada uno de sus miembros, los que, por otra parte, no eran nada fuera de la polis, la que les daba su condición de ser libres. Sólo los gobiernos que se dirigían a alcanzar el bien común eran catalogados de puros, mientras que los que perseguían 
el interés de una parte (cualquiera fuese) eran considerados perversos o impuros: "es evidente, desde luego, que todos los regímenes que miran por el bien común son rectos, desde el punto de vista de lo absolutamente justo, y que cuantos atienden solo a lo particular de los gobernantes son erróneos y todos ellos desviaciones de los regímenes rectos; pues son despóticos y la ciudad es comunidad de hombres libres" (Ibidem:119).

De ese modo,

\begin{abstract}
Los ciudadanos, aunque sean desiguales, es su tarea la seguridad de la comunidad, y comunidad es el régimen político. Por ello la virtud del ciudadano está necesariamente referida al régimen político. (...) La virtud del buen ciudadano, en efecto, debe estar en todos (pues así será mejor la ciudad); mientras que la del hombre bueno es imposible (Ibídem:113).
\end{abstract}

Retomando ese primer concepto de libertad política, fue Benjamín Constant (1767-1830) - filósofo, escritor y político francés de origen suizo - quién, en su intento por rebatir la propuesta rousseauniana de Voluntad General emparentada con tal noción clásica de autonomía, se aventuró a estampar expresamente la diferencia con la concepción moderna. El aporte distintivo de Constant, que lo hace especialmente enriquecedor y propicio para este trabajo, fue que su propuesta teórica comenzaba con poner en clara distinción ambos tipos de libertad, antigua y moderna, propia de dos épocas históricas muy disímiles, y cuya confusión y mezcla podría llevar (por ejemplo de la mano de Rousseau) a peligrosos abusos de poder político y arrebatos contra la independencia individual, tan preciada desde las Revoluciones burguesas. Asimismo, fue uno de los primeros autores en idear una solución de compromiso entre ambos conceptos, sin excluir completamente a uno u otro, poniendo la libertad política, propia del ámbito público y ligada a la participación y control ciudadano, al servicio de la más valiosa libertad individual privada de la persona, ante un Estado que amenazaba devenir omnipotente y/o arbitrario. Dicha complementariedad iría luego a plantearse en todo su potencial, e incluso a profundizarse y ampliarse, en la era posmoderna (como se retomará en el último apartado de este artículo) frente a los 
límites que el neoliberalismo y la concepción negativa y acotada de la política evidenciarían tras los años iniciales del modelo.

En efecto, desde una cosmovisión bastante más liberal que la democrática radical de Jean Jacques Rousseau, Constant criticó el concepto extra-temporal de libertad del ginebrino, asociado a las pequeñas, sencillas y homogéneas ciudadesEstado antiguas, de asambleas soberanas, que hacían posible tal libertad como "participación activa y continua del poder colectivo". Contrariamente, bajo las nuevas condiciones de los tiempos modernos, se haría necesario, para Constant, asumir un significado diferente de la misma, esta vez, en tanto "disfrute apacible de la independencia privada" (Constant, 1989:4).

La noción antigua de libertad, que en su visión "consistía en ejercer de forma colectiva pero directa distintos aspectos de la soberanía", también compatible con "la completa sumisión del individuo a la autoridad del conjunto", era adecuada a las repúblicas de entonces, "encerradas en estrechos límites" y de "espíritu belicoso" (Ibídem:2), pero impensable para las extensas naciones modernas, orientadas hacia la paz y el comercio. Además, la abolición de la esclavitud había "privado a la población libre del ocio que disfrutaba cuando los esclavos se encargaban de la mayor parte del trabajo", tregua necesaria para "deliberar a diario en la plaza pública" (Ibídem:3), y había concedido al individuo un nuevo rol social que, haciéndolo insignificante ante el todo, le daba nuevas y demandantes funciones en su vida privada.

El desarrollo del comercio y el "vivo amor por la independencia individual" inspirado por aquél, disminuyeron la intervención de la autoridad, vista siempre como "una molestia y un estorbo" (Ídem). Asimismo, la completa sumisión del individuo a la soberanía de la nación (Ibídem:5), reinante en la antigüedad, se mostraba entonces incompatible con los nuevos beneficios de la independencia individual moderna.

En el marco de la Modernidad los alcances de la libertad fueron redefinidos como las "garantías concedidas por las instituciones" a los disfrutes privados (Ibídem:4) y el gobierno representativo devino, para Constant, en "el único que puede proporcionarnos hoy cierta libertad y tranquilidad", el que, siendo "un descubrimiento de los modernos", "fue prácticamente desconocido entre las naciones libres de la 
Antigüedad" (Ibídem:1). Pronto John Stuart Mill (filósofo y economista inglés, 18061873) reforzaría tal apreciación:

\begin{abstract}
Es evidente que el único Gobierno que satisface por completo todas las exigencias del estado social es aquel en el cual tiene participación el pueblo entero; que toda participación, aun en las más humildes de las funciones públicas, es útil; que, por tanto, debe procurarse que la participación en todo sea tan grande como lo permita el grado de cultura de la comunidad; y que, finalmente, no pueda exigirse menos que la admisión de todos a una parte de la soberanía. Pero puesto que en toda comunidad que exceda los límites de una pequeña población nadie puede participar personalmente sino de una porción muy pequeña de los asuntos públicos el tipo ideal de un Gobierno perfecto es el Gobierno representativo (Stuart Mill, 1994:43).
\end{abstract}

Tal primacía de la libertad individual como independencia y desde una concepción negativa (consistente en delimitar una esfera de acción personal ajena a intromisiones externas) podía hallarse incluso antes, en las reflexiones de otro pensador contractualista, John Locke (Inglaterra, 1632-1704) según quién, antes de todo orden político, los hombres se hallan por naturaleza en "un estado de perfecta libertad para que cada uno ordene sus acciones y disponga de posesiones y personas como juzgue oportuno, dentro de los límites de la ley de naturaleza, sin pedir permiso ni depender de la voluntad de ningún otro hombre" (Locke, 1998:36). La división y separación de poderes y la opción de "apelar a los cielos" (Ibídem:231), eran resguardos imprescindibles para esa libertad de acción frente a un Estado que, aunque mínimo o gendarme, contaba con amplias posibilidades y disposición de acumular poder y de hacer un mal uso del mismo, poniéndose en estado de guerra contra el individuo. El gobierno debía limitarse a proteger la vida, propiedad y libertad de los habitantes, siendo estos bienes anteriores y superiores a él:

El poder absoluto y arbitrario, o gobernar sin leyes establecidas, no puede ser compatible con los fines de la sociedad y del gobierno. Los hombres no abandonarían la libertad del estado de naturaleza, ni se someterían a una norma, si no fuera porque buscan con ellos preservar sus vidas, sus libertades y sus fortunas, y porque quieren que su paz y tranquilidad sean aseguradas por reglas establecidas en lo concerniente a su derecho y a su propiedad (Ibídem:144) 
Aún más atrás en el tiempo, Thomas Hobbes (filósofo inglés, 1588-1679) acusado de antiliberal y absolutista, concebía a la libertad natural en forma también negativa, como la "ausencia de impedimentos externos, impedimentos que con frecuencia reducen parte del poder que un hombre tiene de hacer lo que quiere; pero no pueden impedirle que use el poder que le resta, de acuerdo con lo que su juicio y razón le dicten" (Hobbes, 1998:106). Luego, bajo el Estado, la libertad, vinculada necesariamente con la vigencia de leyes civiles dictadas por el soberano, no perdía por ello su connotación negativa e individual:

Si advertimos que no existe en el mundo Estado alguno en el cual se hayan establecido normas bastantes para la regulación de todas las acciones y palabras de los hombres, por ser cosa imposible, se sigue necesariamente que en todo género de acciones, conforme a leyes preestablecidas, los hombres tienen la libertad de hacer lo que su propia razón les sugiera para mayor provecho de sí mismos (Ibídem:173).

Tales definiciones eran tanto más acordes al clima de época que la noción rousseaunina de participación positiva, personal y directa de todos los ciudadanos en la toma de decisiones políticas, que otorgaba a la libertad una connotación literal como autonomía.

El error de Rousseau para Constant, consistía en haber confundido ambas libertades, causando infinitos males a pesar de sus nobles intenciones, ya que:

al trasladar a la época moderna una extensión del poder social, de la soberanía colectiva, que pertenecía a otros siglos, este genio sublime a quien animaba el más puro amor a la libertad, ha proporcionado sin embargo funestos pretextos a más de una clase de tiranía (Constant, 1989:4).

La independencia individual, primera necesidad de los modernos, no podía, a sus ojos, ser sacrificada para establecer la libertad política (entendida como participación directa en los asuntos públicos comunes) (Ibídem:6). Por el contrario, sostenía que: 
seguro para apartarles de la primera y, cuando eso se haya logrado, no se tardará en arrancarles la segunda (Ídem)

Lo que Marshall valoraría luego, hacia mediados del siglo XX, como una conquista en el Estado de la tendencia universalista y amplificadora de las libertades, en tanto expansión de la ciudadanía moderna; desde los derechos civiles iniciales (referidos a la defensa de la libertad individual y de la propiedad, ligada a los tribunales de justicia), a la extensión de las facultades políticas (vinculadas con la participación en los procesos de toma de decisiones públicas, en forma activa o pasiva), para sumar finalmente los derechos sociales (conquistas de mínimos de bienestar económico y seguridad social; unida a la provisión de bienes y servicios públicos básicos), estaba, en los comienzos del pensamiento moderno de influencia lockeana y smithiana, invertido en su prioridad e importancia: la política servía exclusivamente para garantizar las condiciones de la esfera civil que se autoregulaba por la "mano invisible" del mercado, siendo las desigualdades económicas producto legítimo de la desigualdad de esfuerzos y capacidades individuales, y donde cualquier otra intervención igualitarista social del Estado, redundaría en una ruptura del justo y conveniente equilibrio entre oferta y demanda.

Avanzado el siglo XX, desde la visión tripartita marshalleana de la ciudadanía, si la igualdad política había permitido consagrar y encubrir la primacía de la desigualdad económica habilitada desde el reconocimiento de los derechos civiles, el Estado protector debía ahora involucrarse activamente en pos del logro del bienestar, para compensar las situaciones extremas de desigualdad económica y garantizar condiciones mínimas de subsistencia con la provisión de servicios básicos fundamentales. Desde una concepción de ciudadanía que se oponía a la de clase, como diferentes status orientados según principios opuestos, aunque ambos igualmente basados en un conjunto de ideales, creencias y valores propios, Marshall comprendía que el status de ciudadanía correspondía a todos los miembros plenos de una comunidad, igualados respecto de sus deberes y derechos, mientras que el de 
clase se encontraba sustentado en un evidente sistema de desigualdad (Sojo, 2002:27). Así, la función central de la ciudadanía consistiría en reivindicar los valores igualitaristas del sistema político democrático frente al avance de los ideales individualistas desigualitarios del capitalismo, a través de la extensión de la equidad de oportunidades y el estímulo a la movilidad social (Ibídem:29). Todo lo cual se encontraba muy lejos del pensamiento liberal económico puro del siglo XVII.

No obstante, y derivando en un acercamiento a la definición de Ruiz Silva presentada al comienzo de este artículo, el concepto republicano de Constant no se limitó a la sola defensa del gobierno representativo y de la libertad como independencia, sino que postuló, asimismo, a modo de freno a la autoridad de los gobernantes y de resguardo de tal libertad individual frente a estos, un medio de vigilancia activa y constante: el derecho liberal de revocatoria de los poderes abusados (Constant, 1989:7), cercano al derecho de resistencia a la opresión lockeano.

Su solución apuntó, novedosamente y reivindicando en parte un lugar para la participación ciudadana en los asuntos públicos (aunque indirecta), a la combinación de ambos tipos de libertades bajo el gobierno representativo establecido: una ligada al ámbito privado del individuo, y la otra concerniente a la participación ciudadana en el poder político, aunque, esta vez, ejercida a través del voto, el control y la vigilancia a los gobernantes, en aseguro de la primera (que era, claro estaba, la más importante) (Ibídem:8): "Lejos pues, señores, de renunciar a ninguna de las dos clases de libertad de las que he hablado, es necesario (...) aprender a combinar una con la otra" (Ídem), "la libertad individual, repito, es la verdadera libertad moderna. La libertad política es su garantía" (Ibídem:6).

Cercano a Constant, otro de los autores emblemáticos del pensamiento político liberal del siglo XIX que se ocupó de "encauzar, dirigir, y limitar aquellas fuerzas que la Revolución insospechadamente había desencadenado, y que en su desenvolvimiento natural amenazaban con arrasar tras de sí el objetivo primero de toda revolución; vale decir: el establecimiento de la libertad" (Carnovale, 2011:7), fue Alexis de Tocqueville (Francia, 1805-1859), pensador, jurista, político e historiador, precursor de la sociología clásica. 
En efecto, a la vista de una fehaciente amenaza para la libertad moderna "negativa", producto de dos corolarios inevitables del avance democrático: la concentración del poder (o despotismo de nuevo tipo) y la tiranía de la mayoría, el autor destacó el valor de la participación popular personal, activa y "positiva" en los asuntos comunes como el principal resguardo para la independencia individual en el marco de las modernas repúblicas representativas. Ambos peligros eran resultado de las tendencias igualadoras, individualistas y masificadoras, características del irrefrenable e irreversible avance democrático.

Así, Tocqueville entendía a la democracia, en primer (y principal) lugar, como un principio de organización social basado en la igualación creciente de las condiciones de existencia, el que podía o no verse acompañado por instituciones acordes con la edificación de la libertad, esta sí, propia del ámbito político.

No sin temor, observaba el irrefrenable e irreversible desarrollo del principio democrático de organización social en tanto voraz tendencia igualitarista enclavada en la auto-percepción de los individuos modernos, cuyo natural devenir arribaría en la materialización de una tiranía de la mayoría en la que la opinión del mayor número se convertiría en ley indiscutible y acallaría o dejaría en total aislamiento a los pareceres minoritarios. Otra de las nefastas consecuencias previsibles de tal desarrollo democrático sería la excesiva concentración del poder en el vértice del gobierno, que terminaría por conformar un despotismo de nuevo tipo facilitado por un desapego general de los hombres respecto de los asuntos públicos comunes, producto del individualismo creciente de personas autodefinidas como iguales, y, por tanto, autorreferenciales, autosuficientes e independientes.

Así, la prevención y defensa más loable contra ambas amenazas propias de la igualación social radicaba, como se evidenciaba en los Estados Unidos, en la multiplicación y el fortalecimiento de las instituciones políticas "libres", que habilitasen una real participación ciudadana en las cuestiones compartidas (libertad positiva), en resguardo y aseguro de la independencia individual (libertad negativa) 
Libertad e igualdad resultaban, así, dos rasgos propios de ámbitos diferentes: el orden político para la primera y la esfera social para la segunda. Siendo la igualdad el valor democrático por excelencia, propio de una sociedad en la que sus individuos ya no toleraban la mínima instancia de privilegio tras el aniquilamiento del orden feudal, la libertad pasaba a ocupar un segundo plano, pudiendo ser incluso sacrificada en manos de un tirano que garantizara condiciones de opresión semejantes para todos, antes de que apoyaran la adopción de instituciones libres pero sustentadas en algún régimen de diferencia.

Tan temible panorama de la democratización social debía ser, por tanto, encausado a través de instituciones políticas libres, las que, sin contradecir las condiciones generales de igualdad, permitieran salvaguardar el espacio de ejercicio de la libertad. Dicha libertad era asumida por Tocqueville, llamativamente en clave rousseauniana, como la participación activa en la cosa pública por parte del ciudadano, pero, en esta ocasión, desde el ejercicio del llamado "interés bien entendido" (y no del "bien común" clásico): un interés individual que, repetido en muchos individuos igualmente impotentes para alcanzarlo por cada uno en forma aislada, adquiría una cierta generalidad entre sus titulares e invitaba al trabajo conjunto para su satisfacción.

Esa participación recomendada por el estudioso de la democracia Americana, tampoco se ejercería en forma directa sino a través de instituciones propias del orden representativo (republicano; electoral; indirecto; de separación, equilibrio y mutuo control entre poderes) como el sufragio universal (soberanía popular), la existencia de cargos electivos, y las instituciones del gobierno municipal, a lo que se sumaba el asociacionismo civil, todo ello a fin de contrarrestar la apatía política, propia del individualismo democrático moderno.

En efecto, este individualismo, inevitable al hombre moderno de las sociedades democrático-igualitarias, se frenaba y reencausaba constructivamente en los Estados Unidos a partir del referido principio del interés bien entendido, ejercido a través de las mencionadas instituciones libertarias: 
A fin de cuentas, no creo que haya más egoísmo entre nosotros que en América; la única diferencia es que hay allí un egoísmo cultivado y aquí no. Todo americano sacrifica una parte de sus intereses particulares para salvar el resto. Nosotros queremos conservarlo todo, y con frecuencia todo se nos escapa (Tocqueville, 1840:8)

El autor daba así una nueva vuelta de tuerca al esfuerzo iniciado por Constant de combinar el orden político representativo de los grandes Estados modernos (despreciado por Rousseau) con una libertad al estilo antiguo de participación personal y activa (aunque ejercida indirectamente por medio de instituciones como el voto, el gobierno municipal, las asociaciones) en la administración de los asuntos comunes.

Para ello, consideró imprescindible entrenar al hombre moderno en el ejercicio de dicho interés bien entendido, siendo que, de lo contrario, "el interés individual se irá convirtiendo cada vez más en el principal, si no en el único móvil de las acciones de los hombres", y frente a una realidad en la cual "no hay poder en la tierra capaz de impedir que la creciente igualdad en las condiciones sociales lleve al espíritu humano hacia la búsqueda de lo útil, y que no predisponga a cada ciudadano a encerrarse en sí mismo" (Tocqueville, 1840:8).

Este principio, capaz de convertir un interés individual específico repetido en un determinado número de habitantes de una comunidad local, que eran impotentes para conseguirlo por sí mismos, en otro fin general de todos los individuos entre los que dicho interés particular se repetía; se erigía, para el autor, en la doctrina "más adecuada a las necesidades de los hombres de la época", al igual que en "la más firme garantía existente contra ellos mismos" (Ídem).

Yes que,

Si los ciudadanos, al hacerse iguales, permanecieran ignorantes y toscos, resultaría difícil prever hasta qué exceso de estupidez podría conducirles su egoísmo, y no sería fácil anticipar en qué vergonzosas miserias se sumergirían ellos mismos por miedo a sacrificar algo de su bienestar a la prosperidad de sus semejantes.

No creo que la doctrina del interés, tal como se predica en América, resulte evidente en todos sus puntos; pero al menos encierra numerosas verdades, y tan evidentes que basta con educar a los hombres para que las vean. 
Educadlos, pues, a toda costa; porque el tiempo de las creencias ciegas y de las virtudes instintivas huye ya de nosotros, veo aproximarse aquel en que la libertad, la paz pública y el orden social mismo no podrán existir sin la cultura (Ídem).

El ámbito más propicio para el cultivo y florecimiento de tal interés bien entendido era la administración municipal; espacio más acotado, cotidiano y tangible para el ciudadano que el del ajeno y distante gobierno nacional o centralizado; que habilitaba un espacio óptimo para el ejercicio práctico de la libertad política desde la participación popular activa; efectivo freno opuesto contra las tendencias democráticas naturales de concentración y absolutización del poder en despotismos y tiranías:

Por mucho que se deje arrastrar por sus pasiones, que pudiese ser la mayoría nacional; por ardiente que sea en sus proyectos, no podría hacer que en todos los lugares, de la misma manera y en el mismo momento, todos los ciudadanos se sometan a sus deseos. Cuando el gobierno central que la representa ha ordenado soberanamente, debe atenerse, para la ejecución de su mandato, a agentes que a menudo no dependen de él y que no puede dirigir a cada instante. Los cuerpos municipales y las administraciones de los condados forman como otros tantos escollos ocultos que retardan o dividen la ola de la voluntad popular. Aunque la ley fuera opresiva, la libertad encontraría todavía un abrigo en la manera de ejecutar la ley; y la mayoría no podría descender a los detalles y, si me atrevo a decirlo, a las puerilidades de la tiranía administrativa. Ni siquiera imagina que puede hacerlo, porque no tiene la entera conciencia de su poder. No conoce todavía más que sus fuerzas naturales, e ignora hasta dónde el arte de gobernar podría extender sus límites (Tócqueville, 2009b) ${ }^{1}$.

Centralización gubernamental pero no administrativa: donde el poder central nacional no llegaba a abarcar las cuestiones menores, específicas y diarias de la vida "real" de los habitantes, tomaban la iniciativa los gobiernos locales, abriendo una brecha propicia para ser llenada con participación ciudadana personal y activa impulsada por el interés bien entendido:

El gobierno central no se ha ocupado nunca más que de un pequeño número de objetos, cuya importancia atrajo sus miradas. No ha intentado arreglar las cosas secundarias de la sociedad. Nada indica que haya concebido siquiera el deseo de realizarlo (Ídem).

\footnotetext{
${ }^{1}$ Aclaración: las citas textuales de Tocqueville (2009 a y b) no llevan número de página porque son extractos de un libro publicado en web, y, por lo tanto, sin distinción de páginas. Artículo completo disponible en http://www.laeditorialvirtual.com.ar.
} 
Tal valorización tocquevilliana del ámbito municipal, donde se asentaban los temas más candentes, cercanos y movilizadores para el involucramiento público del ciudadano medio orientado por su interés egoísta, y, por tanto, óptimo a los fines de la participación ciudadana en cuanto a posibilidades de generalización de ese interés particular y de su conversión en otro "bien entendido", nos conduce al escenario actual crítico de los Estados representativos, donde el reclamo popular por un mayor y mejor ejercicio de la participación política halla su espacio más propicio en los ámbitos jurídico-territoriales sub-nacionales, más inmediatos, reducidos y homogéneos.

Los americanos, se complacen en explicar mediante el interés bien entendido casi todos los actos de su vida. Se complacen en demostrar que un sensato egoísmo les lleva sin cesar a ayudarse unos a otros y les predispone a sacrificar en bien del Estado una parte de su tiempo y de sus riquezas (Tocqueville, 1840:2)

Tal identificación del interés particular con el interés común sólo podía darse, como ocurre hoy en día, en ámbitos municipales más pequeños, donde las cuestiones que afectaban a cada habitante en particular eran similares entre sí y coincidían con las generales de la ciudad en su conjunto.

Otras de las condiciones indispensables para eludir la tiranía de la mayoría según este pensador eran: la independencia del poder judicial ("no sólo con respecto a los otros dos poderes, sino también frente al poder de la mayoría que surja de una votación popular"), la libertad de prensa ("el instrumento democrático de la libertad"), y la existencia de cuerpos intermedios (ya que "una asociación política, comercial y hasta literaria, equivale a un ciudadano más instruido y más poderoso, que no se deja oprimir o coaccionar caprichosamente") (Carnovale, 2011:15).

Finalizando esta sesión, tales reflexiones y propuestas pueden retomarse brevemente de cara a los problemas de nuestros regímenes políticos contemporáneos (profundizados luego en la tercera sesión de este artículo), permitiendo establecer un 
puente entre ambas épocas. Si decimos que las instituciones de la libertad fueron propuestas por Tocqueville y también por Constant (agentes ambos de las elites políticas del siglo XIX post Revolución Francesa) como formas de "oponer vallas de contención a la participación de las masas en la vida política" y de "buscar fórmulas político-institucionales que permitieran domesticar una fuerza que a sus ojos parecía ingobernable" (Ídem); ello invita al menos a pensar si las reformas institucionales impulsadas en los Estados latinoamericanos durante los años '90, que incluían, entre otras medidas, la creación de mecanismos semidirectos de participación ciudadana (como la iniciativa legislativa, la consulta popular, el referéndum vinculante, las audiencias públicas, los presupuestos participativos, los consejos de planeamiento estratégicos, las revocatorias de mandato), no pretendían constituirse como soluciones equivalentes a "amenazas" similares.

Es decir, el ímpetu volcado en la ingeniería institucional participativa a partir de ese decenio, extendido y reforzado sobre el siguiente, enfocado a una actuación ciudadana más directa, personal y activa; pudo haber surgido como una respuesta tentativa a lo que por entonces comenzaba a vislumbrarse como una "crisis de la representación política", caracterizada por el descrédito popular de las instituciones representativas tradicionales, unido a una suerte de apatía política y alejamiento de los gobernantes respecto de sus gobernados.

Los estallidos sociales ocurridos a comienzos del milenio en varios de los países del subcontinente; como en el caso argentino de diciembre de 2001, plasmado en manifestaciones espontáneas y originales (cacerolazos, saqueos, piquetes, asambleas barriales, recuperación de fábricas, marchas, escraches, apagones), que derribó en pocos días a una serie de gobiernos legales pero ilegítimos; exaltaron la creatividad legislativa puesta al servicio de la apertura de nuevos canales de expresión y contención institucional de los humores sociales participativos.

Otra vez, como en el siglo XIX, instituciones de la "libertad", pero ahora una libertad cada vez más positiva con instituciones más directamente participativas, llegaron "desde arriba" para "encauzar" la movilización de la gente, lo que, sin embargo, no dejaría de significar una nueva conquista para la democracia, puesta a disposición de la ciudadanía. 


\section{La edad oscura de la participación positiva: el triunfo (provisorio) de la libertad negativa}

Del conjunto de derechos que hacen a la noción de ciudadanía, a saber, civiles; sociales, económico, culturales; y políticos; en el recorrido hasta ahora realizado en este trabajo y en el tramo que resta aún por atravesar, se ha dado prioridad a la dimensión política, es decir, a aquellas facultades que hacen a la participación de los individuos en los asuntos públicos (Carnovale, 2011:1), aunque también a partir de cierta vinculación con los derechos civiles relativos a la posesión y disfrute de la propiedad privada. Esto es, la relación sociedad civil - sociedad política.

La dimensión política, en la perspectiva moderna asociada a regímenes representativos como la referida por Constant o por Tocqueville, y dejando atrás a la práctica antigua defendida por Rousseau, refiere a:

La participación activa de los ciudadanos en el proceso de toma de decisiones políticas en la comunidad de la que forman parte. Esto significa, fundamentalmente, que todo ciudadano tiene el derecho de elegir mediante el voto a sus representantes y ser elegido como tal para ocupar cargos públicos de gobierno (Ibídem:2).

El dominio de la cosmovisión "negativa" de la libertad política, habilitada en forma mayoritaria, aunque con algunas concesiones "positivas" como las antes descriptas, se hizo evidente en los nuevos Estados constitucionales representativos desde sus comienzos.

En el siglo XX, principalmente en los Estados Unidos desde los años 1920, cuando empezaba a gestarse una nueva forma de comprender y de hacer ciencia (alcanzando incluso a las disciplinas sociales) conocida como la Revolución Conductista (Pinto, 1997), las tímidas reminiscencias de libertad positiva defendidas por cierta teoría y filosofía previa como las aquí repasadas, terminarían por retroceder y desdibujarse casi completamente, redundando en lo que optamos por calificar vulgarmente como "la edad oscura de la libertad positiva". 
Dicho movimiento behavorista, en auge desde los años '50, trajo consigo una forma novedosa de analizar y explicar los fenómenos políticos y sociales, los denominados "enfoques micro", a partir del estudio exclusivo de los actores, que ignoraban o subestimaba, consciente y metódicamente, cualquier influencia proveniente de las lecturas jurídicas, filosóficas e históricas preponderantes en la tradición europea hasta ese momento. Tal perspectiva científica se asentaba cómoda y sostenidamente sobre la tradición pragmatista, vigente tanto en la filosofía como en los valores sociales dominantes de la población estadounidense.

Este proceso, modificó especialmente a las disciplinas sociales, a partir de la adopción de una serie de rasgos característicos bien definidos que se arraigaron fuertemente durante su vigencia, como la incorporación del discurso metodológico positivista, sustentado en premisas empiristas que hacían surgir el conocimiento del procedimiento inductivo, partiendo de la observación de hechos particulares para detectar regularidades y establecer leyes generales más abstractas; así como de un expreso rechazo de la especulación metafísica y de la teoría política, que habían sido predominantes hasta entonces en el mundo europeo.

Tal abordaje, consideraba a la metodología propia de las ciencias naturales como el modelo científico por excelencia, basado en la observación y verificación empírica de los hechos, al cual las demás disciplinas, como las ahora denominadas "ciencias de la conducta", debían acercarse o imitar (monismo metodológico), con una visión de la objetividad en tanto neutralidad axiológica o valorativa, y el uso recurrente y dominante de las técnicas de cuantificación.

Específicamente en la ciencia política, la revolución conductista dejó su impronta en ciertos aspectos prominentes, otorgándole un perfil particular que la convirtió en un estudio empírico de la política. Dicho enfoque defendía la autonomía de la disciplina respecto de la matriz filosófica, jurídica e histórica, desplazando el centro de atención desde las instituciones hacia los actores. Para esta nueva concepción científica, los hechos sociales y políticos eran estudiados y comprendidos como resultados producidos por la pura voluntad política de los individuos, siendo que, a iguales condiciones estructurales le correspondían diferentes resultados según las diversas estrategias de los actores. Esta ciencia política conductista adoptó un enfoque 
metodológico individualista, orientado a la generalización de las uniformidades existentes en los comportamientos políticos individuales, y defensor de la ahistoricidad y de toda lectura que ignorase la subjetividad del hombre.

Esa influencia provino, en parte, de otras ciencias también previamente "behavorizadas", como la psicología (que hizo foco en la readaptación de la conducta humana a través del mecanismo psicológico de estímulo-respuesta, la observación de la personalidad y las motivaciones individuales), la sociología (con su aporte de métodos cuantitativos y herramientas de investigación como las entrevistas en profundidad, las encuestas de opinión, y las técnicas diversas de medición) y, finalmente, la economía (desde su recorte racionalista e individualista, su consideración del individuo como la principal unidad de análisis, la implementación de modelos de equilibrio para la explicación de los fenómenos políticos, y el supuesto del intercambio entre individuos racionales que maximizan sus intereses con creciente eficiencia según sanciones y recompensas).

La teoría, postergada en una primera etapa desde 1920 hasta los años 50', en pos de una mayor aplicación de métodos cuantitativos en el análisis de la conducta política individual, tomó inicialmente un tinte sistémico, cuyos referentes principales fueron Almond y Powell (1978), Easton (1979) y Dahl (1993), en la pretensión de elaborar un marco teórico general adecuado para encuadrar la observación. Luego, en los años 70', hicieron su irrupción las teorías económicas de la política, que, más allá de la diversidad de las corrientes que la integraban, compartían algunos lineamientos comunes: la aplicación de los modelos de equilibrio general de la economía clásica y de los modelos económico-deductivos de análisis político; la concepción del individuo como homo oeconomicus o individuo racional, egoísta y maximizador de beneficios, motivado por el cálculo egoísta racional instrumental medios-fines, que excluía otro motor de la acción como valores, tradiciones, afectos; el principio utilitarista de optimización del placer individual; una visión atomística de la sociedad compuesta por individuos aislados; los lineamientos del individualismo metodológico; la explicación de la acción individual a través de las leyes generales de la conducta humana; la 
conceptualización de las acciones como guiadas por sus consecuencias y no por principios; la defensa de la libre competencia entre individuos sin intervención estatal; y la creencia en el paso de los vicios privados hacia las virtudes públicas, producto de la intervención única de la mano invisible del mercado.

Estas teorías económicas de la política incluyeron dos ramas centrales: la teoría empírica de la democracia, cuyo autor principal fue Schumpeter (1984), y las teorías de la elección racional, en sus tres versiones más conocidas, detentadas por Downs (1992), Olson (1998) y Buchanan \& Tullock (1965).

La primera teoría, la de la democracia empírica, asimilaba el mercado económico al mercado político y estudiaba los fenómenos propios del segundo a partir de las pautas de funcionamiento del primero. Concebía a la democracia como la libre competencia oligopólica de las elites políticas por el voto popular, cuyos protagonistas eran los líderes individuales que conformaban dichas elites en tanto poseían la capacidad de mando y de motivación de la voluntad del pueblo. Contrariamente, los ciudadanos individuales sólo desempeñaban un papel secundario y dependiente, limitado a crear gobiernos a través de un acto aislado y particular como el sufragio. Schumpeter (1984) postulaba la ley de racionalidad decreciente, según la cual los individuos eran menos capaces de tomar decisiones racionales en la medida en que las cuestiones a decidir se alejaban del ámbito inmediato de sus vidas cotidianas. La impronta de Tocqueville, respecto del interés bien entendido, según el cual los individuos se involucraban en los asuntos cotidianos cercanos ( $y$, por ello, en los gobiernos municipales y en las asociaciones civiles) más activamente que en los grandes temas de la administración nacional, puede rastrearse en este momento.

En una línea cercana, las teorías de la elección racional compartían el modelo de hombre racional, egoísta, aislado, en competencia por los recursos escasos, y de racionalidad instrumental utilitaria; el esquema de sociedad atomística, que debía definir políticamente la asignación de tales recursos económicos escasos; la concepción del accionar de los individuos a partir de la elección racional de sus conductas para la maximización de sus objetivos en función del cálculo costobeneficio; la exclusión de la consideración de las acciones fundamentadas socialmente u orientadas ideológica o valorativamente; y la explicación de los hechos políticos y 
sociales como consecuencias de las conductas individuales egoístas, de un hombre replegado sobre sí mismo y escindido de o enfrentado a los demás.

Tres variantes de tal teoría de la elección racional permiten visualizar mejor este predominio, en esos años finales del siglo XX, de la concepción negativa de la libertad política como disfrute apacible de la independencia individual, y cuyo límite principal estaba dado por el igual derecho a la independencia por parte de los demás individuos.

Claramente esta noción de ciudadanía, asumida en el goce de los derechos humanos de libertad, igualdad, propiedad y seguridad, ninguno de los cuales iba "más allá del hombre egoísta, del hombre como miembro de la sociedad burguesa, es decir del individuo replegado en sí mismo, en su interés privado y en su arbitrariedad privada, y disociado de la comunidad" (Marx, 1999:43), dejaba atrás las reminiscencias retomadas por Rousseau, y, aunque en menor y diferente medida por Constant y Tocqueville, de libertad positiva activa de intervención en lo público, que fuera dominante en la Atenas democrática antigua.

Estas teorías economicistas de la política harían las veces de base y marco a "la edad oscura" de la noción y ejercicio de la participación política personal y directa en la decisión de los asuntos colectivos, que había sido propia del hombre definido por su pertenencia a la comunidad, reconciliado con sus congéneres, y bajo la conciencia de un bien compartido que, al menos, se diferenciaba en esencia del puro interés egoísta privado individual, tan inexistente en el mundo antiguo como luego dominante $y$ ensalzado en la etapa moderna.

Así, en primer lugar, aparecía la paradoja del votante de Downs (1992), según la cual la acción gubernamental no estaba ajena a la lógica del mercado; el bienestar social constituía un subproducto de la búsqueda del interés privado individual; los políticos eran individuos motivados por el deseo de obtener cargos; los votantes aparecían como personas que elegían el mejor gobierno acorde con sus intereses; se carecía de información completa, dando lugar al juego de los persuasores y al uso de la ideología para manipular la acción de los votantes, candidatos y políticos, limitados 
todos ellos por tales deficiencias informacionales; y la conducta cívica apática junto con la ignorancia política de los ciudadanos comunes eran elecciones racionales, resultado directo del frío cálculo costo-beneficio, donde la adquisición de información en vistas de una buena decisión política resultaba excesivamente cara e ineficiente, y, por ello, desaconsejable, en comparación con el bajo grado de influencia que los votos individuales ejercían sobre el resultado final entre millones de sufragios.

Otra variante de teoría de la elección racional era la de la lógica de la acción colectiva de Olson (1998), para la cual los bienes públicos sólo se producían cuando reportaban beneficios específicos para cada individuo participante, ya que el interés común y los incentivos colectivos resultaban insuficientes a los fines de motivar a las personas a participar de acciones grupales. Para este autor, los únicos motores de la acción colectiva eran el utilitarismo y la maximización del bienestar individual y no así el altruismo ni la solidaridad social. Dicho interés privado se satisfacía en la acción colectiva sólo si para ello se otorgaban incentivos selectivos positivos y/o negativos. En toda acción grupal subsistía además el problema del free-riding debido a que los bienes colectivos eran indivisibles entre contribuyentes y no contribuyentes, y, a pesar de que el bien público final representaba un resultado conveniente y mejor para el conjunto de los participantes, la irracionalidad de asumir el costo individual de contribuir, desincentivaba la participación de cada uno en la acción colectiva.

La tercera teoría de la elección pública, la de Buchanan y Tullock (1965), analizaba el proceso de toma de decisiones en un contexto ajeno al mercado a partir de la atribución al individuo de iguales motivaciones en su vida económica que en el entorno político, a saber: la búsqueda de la utilidad individual. Cercana a la perspectiva de Schumpeter, esta teoría consideraba a la vida política desde la lógica del mercado económico, por lo tanto, el proceso político era visto como la oferta de medidas y decisiones por parte de los líderes, que actuaban con el solo objeto de captar sufragios para acceder a cargos, a través de la satisfacción de las demandas y expectativas de los votantes. En este sentido, se intercambiaban ganancias electorales por políticas ventajosas, en una negociación política directa, esto es, sin mediaciones ideológicas, organizativas o institucionales. 
Por último, y como ejemplos de enfoques micro o individualistas más contemporáneos, surge la obra de Elster (1991), quién, si bien también asumía que la elección racional instrumental orientada a fines guiaba las acciones de los hombres, reconocía, por otra parte, que dicha racionalidad podía fallar, ya fuera por indeterminación de gustos y preferencias individuales, o por una mala elección del medio en función del fin deseado. Asimismo, Gary Becker (1993) aplicaba la lógica del cálculo económico egoísta individual a todo tipo de acciones y decisiones privadas cotidianas e íntimas de las personas (matrimonio, divorcio, discriminación, acciones delictivas), con independencia de cualquier consideración emocional o afectiva.

En síntesis, el individualismo del hombre moderno tan temido por Tocqueville, desentendido de sus pares y replegado sobre sí mismo, maximizador de ganancias y fines, y ajeno a las cuestiones políticas comunes más amplias, no sólo era asumido por la perspectiva conductista como "la" expresión lógica del hombre moderno sino que, además, era en ese modo ensalzado por sus connotaciones "racionales", donde las motivaciones puramente comunitaristas, desinteresadas, solidarias, que involucrasen la participación en los asuntos públicos comunes más allá de la búsqueda del beneficio particular, eran descartadas entre las explicaciones posibles de la acción como irracional y, por ello, inconcebible.

\section{Crisis de la representación: recuperando la concepción positiva de} libertad política. Una nueva oportunidad para la participación ciudadana directa

Luego del breve paso por los vaivenes de las nociones positivas y negativas de libertad política en las diferentes épocas históricas, presentadas ciertas veces como concepciones incompatibles entre sí pero también, en otras oportunidades, reunidas intencionalmente como respuestas diseñadas frente a situaciones críticas; arribamos finalmente al análisis de las democracias representativas contemporáneas y al del nuevo lugar y vinculación de ambas percepciones en las mismas. 
Para comenzar, encontramos un importante debate teórico y conceptual respecto del escenario por el que atraviesan varios Estados occidentales desde fines de los años '80, calificado por algunos pensadores y perspectivas participativas y deliberativas de la democracia como "crisis de la representación", enfoque que puso en el centro de la escena al reclamo popular elevado en contra del modo en que funcionaban las instituciones indirectas (elecciones, partidos políticos, representantes, órganos de gobierno) y a favor de la apertura de instancias más directamente participativas, como alternativas o complementos de aquellas en situación de decadencia, sumidas en el descrédito, indiferencia y apatía por parte de la población.

De este modo, quienes sostienen la controvertida lectura de una crisis representativa, abogan por la adopción de formas más participativas y/o deliberativas de la democracia, que incorporen con mayor presencia y protagonismo espacios institucionales horizontales para la intervención directa de los ciudadanos en las distintas etapas de los procesos de toma de decisiones políticas, como los llamados mecanismos semidirectos de participación. Así, nuevamente en la incipiente línea abierta por Constant y compartida por Tocqueville, a las instituciones indirectas compatibles con la libertad moderna, negativa e individual, se vendrían a sumar espacios de ejercicio directo de la libertad política positiva, como un intento de solucionar la situación crítica atravesada por la forma pura de democracia representativa.

Para Nino (1997) tal crisis sacudió a los pilares de los regímenes "indirectos" siendo que "los parlamentos y los congresos en las democracias modernas no se corresponden con esta visión de un cuerpo que reproduce la deliberación ideal que la totalidad de la sociedad llevaría a cabo en caso de ser practicable" (Ibídem:237). Sostiene que "muchas de las deficiencias de los parlamentos reflejan las deficiencias de los partidos" (Ídem), los que lejos están de cumplir con las funciones atribuidas como "vehículos necesarios para conducir la discusión pública sobre la base de principios, ideologías o modelos de la sociedad" y de resultar "útiles para contrarrestar el poder de las facciones que unen a los individuos sobre la base de sus crudos intereses" (Ibídem:237-238). 
Roberts (2002) coincide con que, en la actualidad, la modernización social y tecnológica redujo la centralidad de los partidos como agentes de representación política, viendo disputado su rol histórico como organizadores de la sociedad civil por grupos de interés, movimientos sociales y organizaciones no gubernamentales (Ibídem:57). Según Abal Medina (2004), la profesionalización de los partidos y su inclinación hacia funciones prioritariamente electorales, los desvinculó de sus bases sociales concentrándolos en los círculos del poder, redundando en una menor participación y en una mayor volatilidad del voto: "los individuos buscan una relación de transparencia con la política (en general desde lugares 'no políticos'), mediante un vínculo de tipo empático que desprecia cualquier tipo de mediación. Pero sin mediación no hay representación posible" (Medina, 2004:105).

En la misma línea, Piedra Buena aporta el concepto de desciudadanización, por el que entiende "un marcado desinterés por la cosa pública, donde la cultura política juega un rol clave" (2007:196). Habla de un nuevo hombre, el de la sociedad posindustrial, "descreído de la política a causa de la falta de respuestas válidas frente a los desafíos de la nueva realidad" (Ibídem:197). Junto a dicho fenómeno, el autor coloca,

\footnotetext{
por un lado, una serie de formas de participación vinculadas con la solidaridad (...); y, por otro, una sucesión de prácticas políticas tales como cacerolazos, cortes de rutas, bloqueo de edificios, ocupación de empresas cerradas, etc. a las que podríamos calificar como demandas sociales anárquicas, verdaderas formas de participación inusitadas y autoconvocantes, en búsqueda de otros canales alternativos eficaces, frente al desinterés puesto de manifiesto por los partidos políticos en el tratamiento y solución de problemáticas socioeconómicas acuciantes de la sociedad (Ídem).
}

La mentada transición a un nuevo modelo de representación que acompañaba el paso de un Estado de Bienestar a otro "postsocial", de audiencia o neoliberal, caracterizado por la prevalencia de partidos "atrapatodo"; la creciente influencia de los mecanismos de representación "permanente" (como los sondeos de opinión); y la creación y empleo de instituciones participativas, daban así cuenta, para varios autores, de la referida crisis de la representación política del modelo de masas. 
Tal cambio de coyuntura abrió el espacio para el surgimiento de nuevas y diversas perspectivas teórico conceptuales cercanas a la democracia participativa y deliberativa, que contemplaban la creación de innovadores y variados diseños institucionales que, si bien mantendrían el marco representativo (libertad negativa), otorgaban un lugar preponderante a la participación y deliberación ciudadana sobre las decisiones de política pública (libertad positiva).

Entre ellos, Bobbio resaltó el crecimiento de las demandas de participación ciudadana en las democracias contemporáneas, expresadas como un pedido popular generalizado de que las instituciones representativas vinieran apoyadas (e incluso sustituidas) por la democracia directa, un reclamo por "mayor democracia" (2005:49). En la huella de Constant, este autor se oponía a la línea argumental según la cual, desde el siglo XIX, se distinguían, como dos especies diferenciadas de democracia, la directa o pura (antigua, de libertad positiva) y la indirecta, impura o representativa (moderna, de libertad negativa). A su juicio, entre el tipo extremo de democracia representativa y el tipo extremo de democracia directa existía "un continuum de formas intermedias", con lo que "un sistema de democracia integral puede abarcar a las dos, a cada una de acuerdo con las diversas situaciones y las diferentes necesidades, porque son, en cuanto adaptables a diversas situaciones y a diferentes necesidades, perfectamente compatibles entre ellas" (Ibídem:60-61). Finalmente, ante los límites de la democracia política proponía ampliar el proceso de democratización hacia la democracia social. Para él,

\footnotetext{
si se puede hablar hoy de un proceso de democratización, este no consiste tanto, como erróneamente se dice, en el paso de la democracia representativa a la democracia directa, como en el paso de la democracia política en sentido estricto a la democracia social, o sea, en la extensión del poder ascendente, que hasta ahora había ocupado casi exclusivamente el campo de la gran sociedad política (...), al campo de la sociedad civil en sus diversas articulaciones, desde la escuela hasta la fábrica (Ibídem:63).
}

En ese camino, Macpherson también descreía de toda posibilidad de recrear algún tipo de democracia directa en la actualidad: "no podemos prescindir de los políticos elegidos", debiéndose entonces utilizar "la democracia indirecta", "aunque no sea de modo exclusivo" (1982:118). El interrogante que surgía era el de cómo hacer 
que los políticos elegidos fuesen responsables, ya que "la tecnología electrónica no nos puede aportar la democracia directa" (Ídem). A lo que sí podía aspirarse, era al avance hacia alguna forma de "democracia participativa a escala masiva" (Ídem). Partiendo de un sistema actual no participativo o apenas participativo, propio de una sociedad desigual de consumidores y apropiadores en conflicto, con sus elites políticas competitivas y sus votantes apáticos (Ibídem:120), el autor planteaba la necesidad de alcanzar dos requisitos previos para el logro de dicha democracia participativa: cambios en la sociedad, que implicaban una gran reducción de la desigualdad social y económica, desigualdad sustentada en un sistema no participativo de partidos (Ibídem:121); y cambios en la ideología dominante, a partir de los cuales las personas pasaran de verse a sí mismas y de actuar como esencialmente consumidoras a percibirse y actuar como gente que ejercitaba sus propias capacidades y gozaba con su ejercicio y desarrollo (Ibídem:120).

Dahl también analizó las grandes transformaciones producidas en la vida política que derivaron en las modernas nociones y prácticas democráticas: "el desplazamiento gradual de la idea de la democracia desde su sede histórica en la ciudad-Estado al ámbito más vasto de la nación, el país o el Estado nacional" (1993:257) a partir del siglo XVII. Respecto de la petición popular de retornar a algún tipo de democracia directa, descreía que ello fuese factible. El nuevo reinado de la poliarquía había destronado para siempre a la asamblea ciudadana. El único modo de concebir a la democracia en la actualidad era bajo ciertas características ineludibles: funcionarios electos a cargo de las decisiones políticas; elecciones libres e imparciales; sufragio inclusivo para prácticamente todos los adultos; derecho abierto a ocupar cargos públicos; libertad de expresión; variedad de fuentes de información; y autonomía asociativa (Ibídem:267). No consideraba posible el "sueño de la democracia participativa" bajo las condiciones modernas. No obstante, encontraba en los derechos y libertades políticas recientes otras nuevas formas de expresión de la voluntad ciudadana que permitían ejercer algún tipo diferente de influencia en el gobierno. Reconocía que "una de las consecuencias de trasladar la idea de la democracia de la 
ciudad-Estado al Estado nacional es que los ciudadanos tienen menos oportunidades de participar plenamente en las decisiones colectivas de las que tendrían, al menos teóricamente, en un sistema más pequeño" (Ibídem:271). Por ello, admitía la necesidad de buscar una nueva forma de democracia que ampliara las oportunidades de participación y de control ciudadano (bastante limitadas en las poliarquías), tanto en las unidades territoriales más acotadas (donde el proceso democrático podría verse fortalecido) como en las instancias mayores. Sin embargo, tenía dudas sobre los mejores medios de lograrlo.

Desde una perspectiva aún más cercana a la democracia deliberativa, y consciente de la multiplicidad de definiciones existentes sobre la misma, Elster esbozó una primera conceptualización sencilla para empezar a desglosar el tema: "toma de decisiones a través de la discusión entre ciudadanos libres e iguales" (2001:13). Luego precisaría tal concepto al detectar los elementos comunes entre las múltiples definiciones: "la toma colectiva de decisiones con la participación de todos los que han de ser afectados por la decisión o por sus representantes: esta es la parte democrática" (Ibídem:21) y "la toma de decisiones por medio de argumentos ofrecidos por y para los participantes que están comprometidos con los valores de racionalidad e imparcialidad: esta es la parte deliberativa" (Ídem). La democracia deliberativa no excluía la intermediación de los representantes en el debate sobre los asuntos comunes, pero tampoco eliminaba la participación personal y activa de los ciudadanos afectados por alguna medida. Esta amplitud conceptual hacía compatible a la democracia representativa con la deliberación de los mandatarios, pero también habilitaba la reflexión popular conjunta a través de las instancias institucionales creadas a tal efecto. Finalmente, siendo la idea de la democracia deliberativa y su implementación en la práctica algo tan antiguo como la democracia misma (Atenas, siglo $V$ a.C.), estaba experimentando, sin embargo, "una renovación de su vigencia" (Ibídem:13). En sintonía con Dahl señaló como punto de inflexión el fin de la democracia ateniense en el año 322 a.C. y el posterior "resurgimiento del gobierno democrático aproximadamente dos milenios más tarde -pero ahora representativo y no directo", a partir de lo cual, "cambió la naturaleza de la deliberación política" (Ídem). 
Desde una teoría también deliberativa, Nino defendía a la democracia como "el procedimiento más confiable para poder acceder al conocimiento de los principios morales" (1997:154). Su perspectiva dialógica, sustentada en una concepción constructivista respecto del conocimiento de principios de moralidad social, se emplazó en un punto medio, pretendidamente "correcto", entre las posiciones extremas de Rawls y de Habermas. La propuesta de Nino, reunía ambas concepciones, como formas válidas de conocer la pretendida verdad moral:

La discusión y la decisión intersubjetivas constituyen el procedimiento más confiable para tener acceso a la verdad moral, pues el intercambio de ideas y la necesidad de ofrecer justificaciones frente a los otros no sólo incrementa el conocimiento que uno posee y detecta defectos en el razonamiento, sino que ayuda a satisfacer el requerimiento de atención imparcial a los intereses de todos los afectados. Sin embargo, esto no excluye la posibilidad de que a través de la reflexión individual alguien pueda tener acceso al conocimiento de soluciones correctas, aunque debe admitirse que este método es mucho menos confiable que el colectivo, debido a la dificultad de permanecer fiel a la representación de los intereses de otros y ser imparcial (Ibídem:161).

El valor democrático del diálogo radicaba en constituirse en "el mecanismo a través del cual la democracia convierte las preferencias autointeresadas en preferencias imparciales" (Ibídem:202). La representación política era "un mal necesario" ya que: "la intermediación de los representantes en la discusión y decisión podría beneficiar el proceso desde el punto de vista de un mayor conocimiento técnico, pero esto debilita la conciencia y la consideración de los intereses de la gente involucrada en diferentes conflictos" (Ibídem:184). No obstante, y profundizando el planteo de Constant, consideraba que "algún grado de representación es necesario en la comunidad política dada la imposibilidad de la discusión cara a cara a nivel nacional, la complejidad de los asuntos políticos actuales y la necesidad de respetar la autonomía personal" (Ibídem:205), que implicaba dejar libre parte del tiempo para que los ciudadanos persiguieran sus intereses individuales. Un justo medio entre libertad negativa y positiva en las democracias posmodernas. Agregaba que "algunas veces puede ser necesario revocar el mandato de los representantes de modo que la gente común pueda discutir los asuntos públicos en forma directa y decidir por sí 
mismos qué es lo que debería hacerse" (Ibídem:185). De este modo, "resulta ser imperativo buscar formas de democracia directa bajo la concepción deliberativa de democracia" (Ídem). Así, la "representación es un mal necesario" (Ibídem:205) pero "la democracia directa debe ser obligatoria siempre que sea posible" (Ídem), ya que "incrementa la calidad epistémico de la democracia y colabora en lograr que la constitución histórica se aproxime a la ideal" (Ídem).

Donde Nino abrió una puerta, Martí (2006) avanzó un paso: no sólo presentando a la democracia deliberativa como un nuevo modelo democrático con valor epistémico y sustantivo, ideal regulativo a seguir como "utopía válida", sino también ofreciendo nociones básicas sobre el diseño institucional de una "república deliberativa real", tanto respecto de las reformas constitucionales recomendadas y la construcción de su estructura, como de la ampliación y el fortalecimiento de la esfera pública de deliberación no institucional, al igual que de la creación y el empleo de los mecanismos institucionales de participación democrática deliberativa. Consideraba a la inclusión de los diversos mecanismos participativos (iniciativa popular, referéndum, presupuesto participativo y otros), como uno de los pilares centrales que sostenían la edificación de una república deliberativa en las condiciones actuales. La democracia participativa había sentado las bases para el nacimiento de la democracia deliberativa hacia 1980, como propuesta unificadora de distintas alternativas que se habían presentado frente a la crisis del modelo mercantilizado de la democracia, manifiesta en una profunda desafección política causada por el extremo individualismo de las sociedades capitalistas modernas. Para este autor, constituían alternativas

que reclaman un cambio 'en la manera de hacer las cosas', y exploran vías alternativas a las 'viejas' estructuras democráticas que permitan adaptarse a los nuevos tiempos y que, sobre todo, hagan recuperar a los ciudadanos la ilusión por la cosa pública, les implique de forma personal en la toma de decisiones políticas y les haga dignos sujetos de los derechos que tanto ha costado conseguir (Martí, 2006:14).

Así, las nuevas formas democracia participativa se proponían

recuperar los lazos de comunidad, retomar los ideales de autogobierno, y transformar el sistema democrático para hacerlo más permeable a los verdaderos intereses de la ciudadanía, desvinculando la noción de 'interés público' de los intereses egoístas de los individuos, para rehabilitar su voz y 
dignificar el ámbito de la política proscribiendo o limitando los elementos de mercadeo y regateo en la toma de decisiones (Ídem).

Para Martí, la democracia participativa con fundamento filosófico republicano, “aboga por abrir espacios de participación directa de los ciudadanos. Esto es, por poner en marcha mecanismos de participación en los procesos de toma de decisiones, complementarios de las estructuras representativas" (Ibídem:226). Asimismo, daba gran importancia también a la deliberación más amplia, informal y abierta en la que participaban directamente todos los ciudadanos, por lo que demandaba un sistema de representación que vinculara a los representantes con sus representados (mayor accountability y responsiveness).

Otro autor que adscribió a la concepción deliberativa de la democracia fue Gargarella. A su juicio, la incorporación y empleo de mecanismos de "democracia directa" demandaba una idea más deliberativa de la democracia, una noción "más robusta y exigente", "un ideal regulativo" que se diferenciara del poco valor de las expresiones manifestadas por unas cuantas personas en una encuesta. Se preguntaba "cómo deberíamos organizar los sistemas políticos a fin de lograr decisiones imparciales" (Gargarella, 2001:323), cuya respuesta encontraría en combinar ambos tipos de libertades: "'representación plena' más deliberación” (Ídem). La pérdida de legitimidad del sistema político a ojos de la ciudadanía, radicaba en parte en la dificultad de alcanzar decisiones imparciales. Para Gargarella, "si queremos satisfacer los criterios tanto de la deliberación como de la representación plena necesitamos introducir cambios sustanciales en el actual sistema representativo" (Ibídem:324). Las sociedades modernas son plurales, con una multiplicidad de grupos que conforman "coaliciones cambiantes de minorías diferentes" (Ibídem:335). Siendo tantos y tan diversos los intereses "pertinentes", "sería difícil, si no imposible, concebir algún dispositivo institucional que pudiera asegurar la representación de toda la comunidad" (Ídem). La crisis de representación según este autor, refería a la pérdida de las virtudes que el sistema representativo había sabido ostentar tiempo atrás: 
Por un lado, el sistema parece estructuralmente incapaz de tomar en cuenta los puntos de vista de todos los afectados por la toma de decisiones (...) Por otro lado (...) no existen buenas razones para creer que los que tienen el poder tendrán incentivos para proteger los intereses de los individuos comunes como si fueran propios (Ibídem:335-336).

La incorporación de algunas reivindicaciones radicales, como las de participación política, formó parte de la "segunda oleada de reformas importantes" de las últimas décadas, "la respuesta político-jurídica a un nuevo pico de radicalización social” (Ibídem:64-65), a fin de evitar la expansión del socialismo. Así,

aparecidas en un contexto de crisis de representatividad; descreimiento sobre la clase política; desconfianza en los gobiernos; corrupción en torno al Estado de Bienestar; manipulación de la justicia; y preservación o aumento de los niveles preexistentes de desigualdad económica, las nuevas reformas se dirigieron a varios flancos. La mayoría de ellas incluyeron cláusulas creando nuevas instancias participativas, como los plebiscitos y referéndum (Ibídem:65).

En la búsqueda de "un sistema institucional que representa plenamente a toda la sociedad" (Ibídem:338) recomendaba "abandonar la idea de que la política empieza y termina en el Congreso, que la política se reduce a los debates parlamentarios" (Ídem), sino que "deberíamos empezar a considerar que la política extraparlamentaria tiene la misma importancia que la parlamentaria, pensando, al mismo tiempo, en mecanismos para institucionalizar la política que tiene lugar fuera de las puertas del Congreso" (Ídem).

Sobre la misma coyuntura, pero contradiciendo los antiguos diagnósticos y propuestas, Sartori también se expresó sobre las demandas participacionistas elevadas en los últimos tiempos por ciudadanos disconformes con sus gobernantes y partidos. No obstante, lo hizo en términos bien diferentes, encolumnándose en la reivindicación y defensa de las instituciones verticales tradicionales de la democracia indirecta o electoral (propias de la libertad negativa). Definió la democracia, en forma restringida, como el gobierno del pueblo, y las elecciones, como el momento en el que el demos estaba en acto o en función de gobierno: "no se trata de una minimización, puesto que el proceso democrático está encapsulado en las elecciones y en el hecho de elegir" (Sartori, 2005:116). Insistía en que "la prueba democrática es la prueba electoral; pues 
sólo las elecciones expresan un "consenso general", es decir, las opiniones de todo el pueblo (que se preocupa de expresar su opinión)" (Ídem):

las voces que se dejan sentir por encima y más allá de las elecciones son voces minoritarias o de élites; son las voces de una fracción, normalmente reducida, del pueblo. E incluso, millones de manifestantes no son el pueblo mientras se deje sin voz a muchos más millones de ciudadanos (Ídem).

Realzaba el valor de la democracia electoral como democracia gobernada, apuntando que el hecho de "que las democracias estén 'gobernadas' no resta mérito al hecho de que son democracias" (Ibídem:163), "porque en las comunidades políticas occidentales la opinión pública es una fuerza autónoma y porque el poder electoral es un poder efectivo" (Ídem).

Por último, Manín tampoco admitía la mentada "crisis de la representación" como tal, sino como una metamorfosis del tipo específico de representación de masas correspondiente al modo de Estado de Bienestar (1910-1980), tras el cual sucedía una transición a la forma de democracia de audiencia (Manín, 1997:197), propia del Estado neoliberal, desde los años '90. Ese traspaso y modificación del modo en que se asumiría la representación por partidos "atrapatodo" y sin la identificación clasista e ideológica de antaño, con un electorado volátil y desconfiado, en medio de un clima de apatía política, fue asimismo denominado por Abal Medina como el modelo de "democracia electoral" dentro de un nuevo "Estado de la era global" (2010:146-149).

Zuleta Puceiro aplicó el diagnóstico de crisis de la representación a nuestras realidades:

las sociedades latinoamericanas viven hoy una revolución desde la demanda. Informadas e impacientes, descreen de toda receta ideológica preconcebida y desconfían de sus gobernantes, legisladores, jueces, sindicalistas y empresarios -aunque tampoco reconozcan liderazgos de recambio-. Son sociedades informadas e impacientes, movilizadas en defensa de sus derechos, curtidas de decepciones y fracasos, aunque siempre dispuestas a apoyar a quienes ofrezcan ejemplos claros de compromiso, integridad y fortaleza de carácter ${ }^{2}$.

2 "Las izquierdas en su laberinto", por Enrique Zuleta Puceiro, año 2006, disponible en
https://umshare.miami.edu/web/wda/hemisphericpolicy/LaIZQUIERDAeNsUIABERINTO1Mayo2006.pdf. 
Específicamente en la Argentina,

\begin{abstract}
una gran paradoja es que la gente confía menos en los órganos encargados de gobernar que en otras instituciones que no tienen tal responsabilidad. Así, se retroalimentan ciertos procesos y determinadas conductas. Si los argentinos tuvimos como gran cuenta pendiente de nuestra cultura cívica el poco apego al cumplimiento de las leyes, ¿cómo cambiará tal comportamiento si el encargado de producirlas -el Congreso- goza de tan poca confianza? Si el Estado de Derecho debe ser regenerado a través de una mejora de la calidad de la Justicia, ¿cómo hacerlo frente a la desconfianza que impera frente a los jueces? (Serrafero, 2007:25).
\end{abstract}

Más cercano en el tiempo, en España de 2011 “el ánimo de la protesta del 15M estaba conectado con lo que ocurría a nivel internacional. Anteriormente, ciudadanos de Islandia, Irlanda, Grecia y Portugal ya habían salido a las calles para protestar contra sus autoridades, y pocos meses antes también había estallado la primavera árabe" 3 . "El movimiento de indignados en Europa muestra una masa de jóvenes desilusionados con las promesas incumplidas del pasado, con un presente estático y un futuro sin horizontes" ${ }^{4}$ : "un mundo de indignados se ha alzado en el último período histórico. No reconoce territorios, culturas, ni fronteras ideológicas" 5 .

Paralelamente, "en América Latina, ciudadanos indignados luego de los procesos de transición demostraron su disconformidad provocando las caídas de presidentes, por ejemplo en Brasil (1992), en Venezuela (1993), en Ecuador (1997) y hasta en la propia Argentina (2001)”6 . En este último país, durante los últimos años,

los nuevos indignados abominan de la política pero están dispuestos a soportarla todo lo que haga falta. Está en tela de juicio el sistema tradicional de representación $\mathrm{y}$, por un buen tiempo, las soluciones tardarán en articularse. Desde este punto de vista, la contabilidad tradicional de la política tiene poco para aportar. No hay punto de comparación entre este nuevo género de movilización, cognitiva y afectiva y las manifestaciones populares propias de la política tradicional. Ningún líder, partido ni plataforma puede alcanzar la importancia de las nuevas convocatorias ${ }^{7}$.

\footnotetext{
3 "Dos fechas de protestas ciudadanas. 15-M y 12-M: balance y retos", por Salvador Martí i Puig, El Periódico, 15 de mayo de 2012.

4 "Un mundo indignado", por Mario Serrafero, El Estadista, 20 de septiembre de 2011. Versión online disponible en http://elestadista.com.ar/?p=1349.

5 Ídem.

6 ídem.

7 “Democracia de proximidad", por Enrique Zuleta Puceiro, El Estadista, 30 de noviembre de 2012. Versión online disponible en http://elestadista.com.ar/?p=2955.
} 
Por cierto, frente a la crisis de legitimidad en que muchos pensadores contemporáneos advierten se subsumen las instituciones verticales de la política, y ante los límites de las concepciones netamente representativas del gobierno teorizadas por visiones puramente procedimentales de la democracia que conciben la ciudadanía en términos sólo indirectos y pasivos, se alza una nueva voz "desde abajo" en pos de la creación de otros espacios, institucionales y no institucionales, por los que canalizar en forma directa sus demandas, con reminiscencias del espíritu antiguo o rousseauniano de libertad positiva entendida como involucramiento personal y activo en los asuntos públicos comunes.

La concepción ciudadana de Ruiz Silva que incorpora los aspectos tanto "negativos" de acatamiento como "positivos" de ejercicio de los derechos y libertades civiles y políticas, es por ello adecuada y prometedora para estos tiempos. Sobre la huella abierta tímidamente por Constant, profundiza la apuesta e incluye una primera instancia de obediencia pasiva como accionar obligatorio de los súbditos bajo el Estado, donde:

acatar la ciudadanía significa, al menos, tener conciencia de que se hace parte de un orden social e institucional que se encuentra regido por normas de convivencia que nos cobijan a todos, como individuos y como parte de grupos sociales específicos con los cuáles podemos identificarnos. Al acatar la ciudadanía nos hacemos partícipes de una idea de "ciudad" articulada social e históricamente (Silva, 2009:1-2).

Es decir, incorpora las condiciones propiamente formales (y "negativas" o restrictivas) de la ciudadanía: ser titular de derechos, vivir en un régimen democrático, respetar las normas y leyes de la Constitución, votar... Sin embargo, ello no garantiza el aspecto de ejercicio ("positivo" o activo) de la ciudadanía, la práctica propia del ciudadano autónomo, como parte integrante del cuerpo soberano. Para Ruiz Silva,

ser ciudadano activo, por otra parte, significa ejercer con sentido de responsabilidad un rol político, que en buena medida se define en la participación de proyectos colectivos en los que se hace tangible la idea de la construcción o reconstrucción de un orden social justo e incluyente (Ibídem:2). 
Esta doble condición se vincula, a su vez, con "dos formas genéricas y complementarias de ejercer la ciudadanía: una defensiva y otra propositiva" (Ídem). Por la primera, se participa de modo pacífico en el reclamo, la demanda o la exigencia de derechos amenazados o atropellados a través de instituciones legales y legítimas; por la segunda, se toma parte en acciones pacíficas de reforma política y/o normativa para eliminar injusticias o para ampliar las condiciones de equidad social.

En síntesis, la noción contemporánea de ciudadanía y, con ella, de libertad política, engloba tanto el carácter de construcción como de cumplimiento de la norma. El ciudadano debe ser "capaz de darse a sí mismo la norma -autonomía- (habiendo participado en su construcción o significación)", y "que vele por su cumplimiento en la vida pública, esto es, en la regulación de acciones orientadas a la preservación del interés general" (Ibídem:5).

Ese doble carácter de la concepción de ciudadanía puede esbozarse también ligado a "la idea de derechos individuales por un lado, y a la noción de pertenencia a una comunidad, por otro" (Carnovale, 2011:2). Esto es, "una relación política entre un individuo y una comunidad", "cristalizada en un status jurídico en virtud del cual el individuo es reconocido como miembro de pleno derecho de una comunidad de iguales y asume ante ella una serie de deberes vinculados a la esfera pública" (Ídem).

De este modo, podemos asociar, de una parte, la dimensión "constructiva" o positiva de la ciudadanía con "la pertenencia a una comunidad", y, de la otra, la condición de "acatamiento" o negativa con la posesión de derechos individuales. El resultado es un ciudadano que, en su rol político, como miembro del soberano, es copartícipe hacedor de la ley y la política pensando en el bien de la comunidad toda, constructor, ejecutor, libre en el sentido activo "positivo" de la participación en los asuntos públicos; mientras que, en su función cívica, es un súbdito que obedece en forma pasiva las normas que rigen el Estado, sirviendo a sus intereses privados y disfrutando de su esfera individual de libertad "negativa" según la cual puede hacer lo que está permitido, lo que no está prohibido y aquello no legislado que no entorpece el igual derecho de los demás. 
Es por ello que, sin negar la aún imprescindible noción negativa de libertad política, ligada a los gobiernos representativos también lógicamente necesarios para los Estados modernos, la emancipación política restringida al solo derecho de voto o a la división y equilibrio de poderes o a la competencia libre y abierta entre partidos, se torna a todas luces insuficiente. Si bien tampoco se abona ya la posibilidad de concretar la utópica vuelta a un régimen de democracia puramente directa; surge, no obstante, otra grieta de la representación a partir de la cual la participación política personal, activa, directa y comunitaria, puede nuevamente y con mayor fortaleza, hacerse presente.

El reciente auge de las teorías participativas y deliberativas de la democracia, antes presentadas a través de Bobbio, Macpherson, Nino, Martí, Gargarella, entre otros, así como el diseño, la creación y el uso de mecanismos de participación ciudadana más directos, dan claras señales al respecto.

\section{Algunas reflexiones finales}

Como afirma Schujman "si bien es muy importante el conocimiento de teorías filosóficas sobre la moral, la formación ética y ciudadana tiene objetivos eminentemente prácticos ya que no busca sólo propiciar la comprensión de los diversos aspectos de la acción moral sino también lograr que cada uno decida responsablemente cómo actuar en cada caso" (2011:15). Si bien "la ética está presente junto a la formación para la ciudadanía", "este conocimiento no será suficiente. La ética al servicio de la ciudadanía debiera ser entendida como saber práctico, como un saber actuar en una situación determinada y en un contexto específico. Y ese saber no se transmite con el mero estudio de las teorías filosóficas" (Ibídem:16).

Por lo tanto, aunque la noción de ciudadanía conlleva una importante dimensión filosófica que la atraviesa y la define y redefine a lo largo del tiempo, es asimismo y, principalmente, un hacer, una formulación que cobra pleno sentido en su ejercicio y en los nuevos alcances y significaciones que conquista en su camino. Las 
consideraciones filosóficas son entonces mejor acompañadas, precedidas o sucedidas por modificaciones concomitantes de la práctica.

En esa línea, los desarrollos teóricos participativos y deliberativos de la democracia en los últimos 30 años fueron de la mano de numerosos y amplios debates sobre reforma política, especialmente en la década de los 90', como posibles soluciones institucionales a las crecientes manifestaciones críticas. Tales proyectos de reforma incluyeron opciones innovadoras en términos de inaugurar, ampliar y reproducir nuevos espacios institucionales de expresión popular más directa. La proliferación de mecanismos de participación ciudadana como las iniciativas populares, las consultas populares, los referéndums, las revocatorias de mandato, las audiencias públicas, los presupuestos participativos, los consejos de planeamiento estratégico, entre otros, plasmó, en términos prácticos y concretos, la respuesta de los políticos a las protestas sociales en aumento.

Así, se gestaron nuevos espacios más afines a la noción positiva de libertad política, en los que la ciudadanía, insatisfecha con los límites de la libertad negativa, pudiera canalizar en forma más activa, personal y directa su involucramiento en la decisión, control y gestión de las demandas e intereses comunes. Espacios de encuentro, deliberación y acuerdo con los demás ciudadanos y con los gobernantes, que, con cierta frecuencia, alternase y complementase la persecución de metas individuales privadas, prioritarias (pero no exclusivas) de los tiempos posmodernos.

En efecto, los años '80 trajeron consigo un contexto controvertidamente calificado por varios observadores de "crisis de la representación política", que, a ojos de Manin no constituía sin embargo más que el agotamiento de una forma particular de representación y el paso a una nueva modalidad de relación representanterepresentado de tipo audiencia (1997:196) o "postsocial" (Abal Medina, 2004:108109), sustentada en una opinión pública que, como tribunal anónimo, observaba y juzgaba constantemente a sus gobernantes.

De ese modo, frente a la imprecisión, contingencia y parcialidad que los nuevos sondeos de opinión ponían en evidencia, que convertían a los políticos en "dramaturgos" de la "video-política" (Sartori, 1998:66), dominados por el ritmo de los medios masivos de comunicación y en base al creciente cuestionamiento del valor 
último de la representación por parte de los desconfiados ciudadanos de las democracias actuales, se hizo urgente indagar en otros caminos posibles que, si bien ya no podrían prescindir del sistema representativo, sí, en cambio, lograsen aliviarlo de presiones, fortalecerlo y complementarlo.

Entre tales caminos alternativos se presentó la opción de ahondar y extender la huella comtiana iniciada algunos siglos atrás, a partir de multiplicar los espacios institucionales semidirectos de expresión "positiva" de la ciudadanía, de forma complementaria a las tradicionales instituciones indirectas de la libertad "negativa".

Así, los autores revisados en la última sesión de este artículo, principalmente aquéllos de perspectiva participativa y/o deliberativa de la democracia, coincidieron en mayor medida en recomendar la adopción y utilización de formas semidirectas de participación en entornos institucionales que, según sus diagnósticos, atravesaban dichas situaciones de grave crisis de la representación política.

Partiendo de la aceptación de una realidad que ni el propio Rousseau pudo desconocer en su momento, a saber, las enormes dimensiones territoriales de los Estados modernos, el crecimiento monumental de la población, y su gran diversidad y heterogeneidad, que volvían imposible el sueño del autogobierno al estilo ateniense antiguo; y frente a los reclamos ciudadanos contra los partidos, los políticos y sus instituciones de gobierno, tales pensadores comprendieron que lo que estaba en juego ya no era el retorno a la democracia clásica directa, ni la vigencia de la democracia representativa en su formato original, sino los modos concretos en los que esta última podía conceder al pueblo soberano nuevos espacios institucionales deliberativos y participativos de manifestación directa de sus demandas y de intervención en los procesos de política pública.

Lo que Justo López (1997) designaba con el nombre de "democracias representativas impuras" aparecía como uno de los posibles caminos de salida a la crisis política. Si por tales democracias impuras se entendía la inclusión de mecanismos semidirectos de participación en los sistemas representativos de gobierno, se llegaba a una situación en la que, si bien dichos mecanismos no excluían la centralidad de los 
representantes y sus instituciones indirectas (imprescindibles en los tiempos modernos y posmodernos), abrían, por cierto, nuevas instancias de expresión de la voluntad popular, fundamentales para canalizar las diversas y múltiples demandas ciudadanas emergentes.

Si bien estos dispositivos podían facilitar la canalización y el procesamiento institucional de las demandas populares, las que ya no eran representadas en forma satisfactoria por los partidos y los gobernantes, no anulaban por ello la democracia electoral vertical sartoriana, la que, a pesar de las dificultades que encontraba en las condiciones actuales de la sociedad posmoderna, seguía constituyendo el único modo viable de gobierno conocido para los grandes Estados.

Sin embargo cabe advertir que, a pesar de que dichos mecanismos pueden brindar espacios interesantes para la identificación de problemas comunes y el diseño, la elaboración y la implementación de ciertas políticas públicas, presentan, como advirtieron varios de los autores consultados, diversos inconvenientes al momento de ser aplicados (como el efecto mayoritario de las votaciones, la parcialidad en la formulación de las preguntas, la propensión a la manipulación, la cierta incompatibilidad con el marco constitucional liberal puro, entre otros), que los alejaban de los óptimos resultados esperados.

Asimismo, la distancia y desconfianza de muchos ciudadanos respecto de los políticos y de las instituciones por ellos promovidas (incluso las participativas o semidirectas), así como su apatía, individualismo y falta de conocimiento profundo y especializado sobre algunos asuntos públicos comunes, puede también entorpecer el buen desempeño de tales mecanismos.

Es decir, que mientras dichos instrumentos de autogobierno pueden ofrecer canales alternativos y/o complementarios de participación popular directa y positiva en los entornos institucionales representativos, indirectos o de libertad negativa, sus desempeños reales y concretos y su verdaderos aportes a la legitimación, ampliación y fortalecimiento de la democracia en términos participativos y/o deliberativos, dependerán asimismo de las actuaciones finales y compromiso tanto de los gobernantes como de los ciudadanos. 


\section{Referências bibliográficas}

Abal Medina, J. M. 2004. La muerte y la resurrección de la representación política, Buenos Aires: Fondo de Cultura Económica.

Abal Medina, J. M. 2010. Manual de ciencia política, Buenos Aires: Eudeba.

Aguirre García, J. C. y Jaramillo Echeverri, L. G. 2006. "El Otro en Lévinas: Una salida a la encrucijada sujeto-objeto y su pertinencia en las ciencias sociales", In: Revista Latinoamericana de Ciencias Sociales, Niñez y Juventud. Vol. 4, № 2.

Almond, G. y Powell, B. 1978. Comparative politics: system, process, and policy, Boston: Little Brown.

Aristóteles. 1998. Política, Buenos Aires: Alianza. $1^{\circ}$ Edición 330 a.C.

Becker, G. 1993. "The economic way of looking at behaviour", The Journal of Political Economy, Vol. 101, No. 3. (Jun., 1993), pp. 385-409, disponible en http://links.jstor.org/sici?sici=00223808\%28199306\%29101\%3A3\%3C385\%3ANLTEWO\%3E2.0.CO\%3B2-X.

Bobbio, N. 2005. El futuro de la democracia, México: FCE.

Buchanan, J. M. y Tullock, G. 1965. The Calculus of Consent: Logical Foundations of Constitutional Democracy, University of Michigan Press.

Bobbio, N. 1984. El futuro de la democracia, México: FCE.

Carnovale, V. 2011. "Dimensión histórica de la ciudadanía", Caicyt - CONICET, Buenos Aires.

Constant, B. 1989. De la libertad de los antiguos comparada con la de los modernos (Conferencia pronunciada en el Ateneo de París, Febrero de 1819; Centro de Estudios Constitucionales - Universidad de Valladolid.

Dahl, R. 1993. La democracia y sus críticos, Barcelona: Paidós.

Downs, A. 1992. "Teoría económica de la acción política en una democracia", In: Diez Textos Básicos de Ciencia Política, Barcelona: Ariel.

Easton, D. 1979. Esquema para el Análisis Político, Buenos Aires: Amorrortu.

Elster, J. 1991. El Cemento de la Sociedad. Las Paradojas del Orden Social, Barcelona: Gedisa.

Elster, J. 2001. "Introducción”, In: Elster, J. (comp) La Democracia Deliberativa, Barcelona: Gedisa, pp. 13-33.

Gargarella, R. 2001. "Representación plena, deliberación e imparcialidad", In: Elster, J. (comp) La Democracia Deliberativa, Barcelona: Gedisa, pp. 323-346. 
Hobbes, T. 1998. Leviatan. O la materia, forma y poder de una República eclesiástica y civil, México: Fondo de Cultura Económica. $1^{\circ}$ Edición 1651.

Locke, J. 1998. Segundo Tratado sobre el gobierno civil, Madrid: Alianza Editorial. $1^{\circ}$ Edición 1689.

Macpherson, C. 1998. La democracia liberal y su época, Madrid: Alianza.

Manín, B. 1997. The Principles of Representative Government, Cambridge: Cambridge University Press.

Marshall, T. y Bottomore, T. 1997. Ciudadanía y clase social, Madrid: Alianza. $1^{\circ}$ Edición 1950.

Martí, J. L. 2006. La República Deliberativa. Una teoría de la democracia, Madrid: Marcial Pons.

Marx, K. 1999. "La cuestión judía", In: Marx, K. La cuestión judía y otros escritos, Lanús Oeste: CS Ediciones. $1^{\circ}$ Edición 1843.

Mill, J. S. 1994. Del gobierno representativo, Madrid: Tecnos. $1^{\circ}$ Edición 1861.

Nino, C. 1997. La constitución de la Democracia Deliberativa, Barcelona: Gedisa.

Olson, M. 1998. "La lógica de la acción colectiva", In: Saiegh, S. y Tommasi, M. La Nueva Economía Política: Racionalidad e Instituciones, Buenos Aires: Eudeba.

Piedra Buena, C. A. 2007. "Crisis de partidos políticos en la Argentina: aproximación a un diagnóstico de su situación actual", In: Ancarola, G. et al. Calidad institucional o decadencia republicana, Buenos Aires: Lajouane, pp. 179-204.

Pinto, J. 1997. Introducción a la Ciencia Política, Buenos Aires: Eudeba.

Roberts, K. 2002. "El sistema de partidos y la transformación de la representación política en la era neoliberal latinoamericana", In Cavarozzi, M. y Abal Medina, J. M. (comps.) El asedio a la política. Los partidos latinoamericanos en la era neoliberal; Rosario: Homo Sapiens; pp. 55-76.

Ruiz Silva, A. 2009. "Retos y posibilidades de la formación ciudadana", In: Revista Novedades Educativas, $\mathrm{N}^{\circ} 220$, abril.

Sartori, G. 1998. Homo videns. La sociedad teledirigida, Madrid: Taurus

Sartori, G. 2005. Teoría de la democracia, Madrid: Alianza Universidad.

Schujman, G. 2011. "Valores, moral y ética en la formación ciudadana. Discusiones téoricas y currículum", Caicyt-CONICET, Buenos Aires.

Schumpeter, J. 1984. Capitalismo, socialismo y democracia, Barcelona: Ediciones Folio.

Serrafero, M. 2007. "Calidad institucional: cuestiones y desafíos", In: Ancarola, G. et al. Calidad institucional o decadencia republicana, Buenos Aires: Lajouane.

Sojo, C. 2002. "La noción de ciudadanía en el debate latinoamericano", In: Revista de la CEPAL. $N^{\circ}$. 76; abril, Chile: CEPAL. 
Tocqueville, A. (de) 1840. "Como frenan los americanos el individualismo con el principio del interés bien entendido", In: La Democracia en América; Tomo II, 2a Parte, Cap. VIII, pp. 3, disponible en http://www.alcoberro.info/pdf/tocqueville.pdf.

Tocqueville, A. (de) 1980. La Democracia en América, Madrid: Alianza. 1ºdición 1835-1840.

\begin{abstract}
About Constant's footprint: the crisis of representation and the return to citizen participation

This article begins with the Constant's view about how the notion of freedom was built in different historical times, starting with the positive freedom of the ancient Greeks to the conceptualization of negative freedom of modern age.

This position invites deepening on the concomitant process of building citizenship for different philosophical perspectives and democratic environments to which they relate, and concluded that the two opposite ways of perceiving political participation (direct, personal and active for Athenians and indirect, passive and representative for modern individuals) become complementary in contemporary democratic republics.

Such coexistence and complementarity of the two notions of political freedom nowadays, appears as the foundation of one of the solutions offered to the crisis of mass representation model since the early '80s: the creation of mechanisms of popular participation driven by the rulers for their use by citizens.

Key-words: Citizenship, Freedom , Political Participation
\end{abstract}

Tramitación del artículo

Sometido: 06/08/2013

Revisiones requeridas: 30/09/2013

Versión corregida: 25/09/2013

Aceptado: 01/11/2013 